\title{
PENGARUH GOOD CORPORATE GOVERNANCE DAN UKURAN PERUSAHAAN TERHADAP KINERJA PERUSAHAAN PT.HM SAMPOERNA TBK PERIODE 2008-20017.
}

\author{
Hepiana Patmarina ${ }^{1}$, Vania Febriana ${ }^{2}$ \\ Fakultas Ekonomi Universitas Bandar Lampung \\ Jl. Z.A Pagar Alam No.26 Labuhan Ratu Bandar Lampung 35142 \\ Telp.0721-701979 Fax. 0721- 701463. \\ Email: hepiana@ubl.ac.id; vania.febriana@studentubl.ac.id
}

\begin{abstract}
ABSTRAK
Penerapan prinsip Good Corporate Governance secara konkret memiliki beberapa tujuan, antara lain memudahkan akses terhadap investasi domestik maupun asing, mendapatkan cost of capital yang lebih murah, memberikan keputusan yang lebih baik dalam meningkatkan kinerja ekonomi perusahaan, meningkatkan keyakinan dan kepercayaan stakeholder terhadap perusahaan. Ukuran perusahaan juga dapat memengaruhi hasil yang akan dicapai perusahaan dengan memanfaatkan aset dengan baik.

Permasalahan dalam penelitian adalah "Apakah Good Corporate Governance dan Ukuran Perusahaan berpengaruh secara parsial maupun simultan terhadap Kinerja Perusahaan PT. HM Sampoerna”. Tujuan yang hendak dicapai dalam penulisan skripsi ini yaitu untuk mengetahui apakah indikator dari Good Corporate Governance dan Ukuran Perusahaan berpengaruh secara parsial dan simultan. Penelitian ini menggunakan metode analisis deskriptif dan kuantitatif dengan menggunakan analisis regresi linear berganda, uji T dan uji F. Hipotesis dalam penelitian ini yaitu Good Corporate Governance dan Ukuran Perusahaan berpengaruh secara parsial maupun simultan.
\end{abstract}

Kata kunci : Good Corporate Governance, ukuran perusahaan, kinerja perusahaan

\begin{abstract}
The application of the principles of Good Corporate Governance concretely has several objectives, including facilitating access to domestic and foreign investments, obtaining cheaper cost of capital, providing better decisions in improving the company's economic performance, increasing stakeholder confidence and trust in the company. The size of the company can also influence the results that the company will achieve by utilizing assets well.

The problem in the research is "Does Good Corporate Governance and Company Size have a partial or simultaneous effect on the Company Performance of PT. HM Sampoerna ". The purpose to be achieved in writing this thesis is to find out whether the indicators of Good Corporate Governance and Company Size have a partial and simultaneous effect. This study uses descriptive and quantitative analysis methods using multiple linear regression analysis, $\mathrm{T}$ test and $\mathrm{F}$ test. The hypothesis in this study is that Good Corporate Governance and Company Size have a partial or simultaneous effect.
\end{abstract}

Keywords: Good Corporate Governance, company size, company performance 


\section{I . PENDAHULUAN}

Penerapan Good Corporate Governance dimulai sejak pasca krisis besar yang melanda Indonesia ditahun 1997. Indonesia mengalami penurunan yang sangat drastis kala itu. Banyak perusahaan yang tidak bisa bertahan, sehingga sebagian perusahaan bahkan dinyatakan tutup atau bangkrut. Krisis keuangan tersebut disinyalir sebagai akibat dari lemahnya tata kelola perusahaan (Corporate Governance) di negara Asia, khususnya di Indonesia (Darmawati, Khomsiyah, dan Rahayu, 2004). Sejak krisis tersebut pemerintah mulai gencar dalam menekankan tata kelola perusahaan sehingga melatar belakangi munculnya Good Corporate Governance di Indonesia.

Di Negara Indonesia, isu mengenai good corporate governance mengemuka setelah Indonesia mengalami krisis yang berkepanjangan sejak tahun 1998. Sejak saat itulah, pemerintah maupun investor memberikan perhatian yang lebih dalam praktek corporate governance.

Corporate governance yang lemah menjadi salah satu penyebab terjadinya peritiwaperistiwa penting tersebut. Ciri utama dari lemahnya corporate governance adalah adanya tindakan mementingkan diri sendiri di pihak manajer perusahaan (Darmawati dkk, 2004).

Sistem corporate governance yang baik akan memberikan perlindungan efektif kepada para pemegang saham dan kreditur untuk memperoleh kembali atas investasi dengan wajar, tepat dan seefisien mungkin, serta memastikan bahwa manajemen bertindak sebaik yang dapat dilakukannya untuk kepentingan perusahaan ( Sukamulja, 2004).

Ukuran perusahaan adalah rata -rata total penjualan bersih untuk tahun yang bersangkutan sampai beberapa tahun. Dalam hal ini, penjualan lebih besar daripada biaya variabel dan biaya tetap , maka diperoleh jumlah pendapatan sebelum pajak. Perusahaan yang sudah besar akan lebih mudah mendapatkan akses pendanaan atau pinjaman dari luar sehingga kesempatan untuk memenangkan persaingan lebih besar. Perusahaan besar yang sudah well-estabilshed akan lebih mudah memperoleh modal dari pasar di pasar modal dibanding dengan perusahaan yang kecil, karena perusahaan yang besar sudah memiliki fleksibelitas yang lebih besar pula, sartono (2010:249). Kinerja keuangan perusahaan dipengaruhi oleh banyak faktor, salah satunya adalah corporate governance.
Kinerja perusahaan dengan pengukuran rasio keuangan tidak dapat dipisahkan dari ukuran perusahaan yang dicerminkan dengan total aset yang dimiliki. Beberapa penelitian terdahulu mengenai ukuran perusahaan menyatakan bahwa ada pengaruhnya terhadap kinerja perusahaan. Besar kecilnya suatu perusahaan dapat ditentukan dengan beberapa hal, antara lain : total penjualan, total aset, rata-rata tingkat penjualan dan rata-rata total aset dimana mempengaruhi kinerja tapi tidak secara langsung.

Berdasarkan uraian di atas, maka peneliti tertarik untuk melakukan penelitian dengan judul

\section{" PENGARUH GOOD CORPORATE GOVERNANCE DAN UKURAN PERUSAHAAN TERHADAP KINERJA PERUSAHAAN PT.HM MANDALA SAMPOERNA TBK periode 2008-2017 “}

\section{RUMUSAN MASALAH}

Berdasarkan latar belakang masalah, identifikasi masalah serta batasan masalah, maka dapat dirumuskan masalahnya sebagai berikut :

1. Apakah Good Corporate Governance berpengaruh secara parsial terhadap kinerja perusahaan?

2. Apakah Ukuran Perusahaan berpengaruh secara parsial terhadap kinerja perusahaan?

3. Apakah Good Corporate Governance dan Ukuran Perusahaan berpengaruh secara simultan terhadap kinerja perusahaan?

\section{TUJUAN PENELITIAN}

Tujuan dilakukannya penelitian ini adalah untuk mengetahui apakah ukuran dewan komisaris (board size) dan komite audit sebagai indikator dari Good Corporate Governance serta ukuran perusahaan berpengaruh secara parsial maupun simultan terhadap kinerja keuangan perusahaan PT.HM Sampoerna tbk.

\section{II . TINJAUAN PUSTAKA}

\section{Good Corporate Governance ( GCG )}

Definisi dari Corporate Governance menurut para ahli yaitu (Surya danYustiavanda, 2006): Komite Cadbury mendefinisikan Corporate Governance sebagai: " Sistem yang mengarahkan dan mengendalikan perusahaan 
dengan tujuan, agar mencapai keseimbangan antara kekuatan kewenangan yang diperlukan oleh perusahaan, untuk menjamin kelangsungan eksistensinya dan pertanggung jawabkan kepada stakeholders yang berkaitan dengan peraturan kewenangan pemilik, direktur, manajer, pemegang saham, dan sebagainya". Keputusan Menteri Badan Usaha Milik Negara Nomor KEP117/M-MBU/2002, corporate governance adalah: "Suatu proses dari struktur yang digunakan oleh organ BUMN untuk meningkatkan keberhasilan usaha dan akuntabilitas perusahaan guna mewujudkan nilai pemegang saham dalam jangka panjang dengan tetap memperhatikan kepentingan stakeholder lainnya, berlandaskan peraturan perundangundangan dan nilai-nilai etika”.

Dewan komisaris merupakan organ perseroan kedua dalam struktur corporate governance yang memiliki fungsi kontrol dalam perusahaan. Fungsi kontrol yang dilakukan oleh dewan komisaris bertujuan untuk melakukan pengawasan secara umum dan atau khusus sesuai dengan anggaran dasar serta memberi pertimbangan-pertimbangan kepada direksi. Komite audit adalah organ tambahan yang diperlukan dalam pelaksanaan GCG. Komite audit ini dibentuk oleh dewan komisaris untuk melakukan pemeriksaan atau penelitian yang dianggap perlu terhadap pelaksanaan fungsi direksi dalam melaksanakan pengelolaan perusahaan serta melaksanakan tugas penting berkaitan dengan sistem pelaporan keuangan. Anggota komite audit harus memiliki keahlian yang memadai.

\section{Ukuran Perusahaan}

Definisi ukuran perusahaan menurut Bambang Riyanto (2008:313) adalah sebagai berikut: "Besar kecilnya perusahaan dilihat dari besarnya nilai equity, nilai penjualan atau nilai aktiva”. Perusahaan besar dianggap telah mencapai tahap kedewasaan yang merupakan suatu gambaran bahwa perusahaan tersebut relatif lebih stabil dan lebih mampu menghasilkan laba dibandingkan perusahaan kecil yang masih dalam perkembangan ( Riyanto, 2011).

\section{Kinerja Perusahaan}

Perusahaan merupakan suatu entitas tempat terjadinya suatu kesatuan dari berbagai fungsi operasional yang secara sistematis bekerja untuk mencapai suatu tujuan tertentu.
Tujuan yang akan dicapai tersebut seringkali dikenal dengan istilah kinerja.Dapat diartikan bahwa kinerja merupakan suatu gambaran dari tingkat pencapaian hasil atas pelaksanaan suatu kegiatan operasional.

Untuk menghasilkan kinerja yang sesuai dengan tujuan perusahaan, semua pihak yang berkepentingan dalam perusahaan harus bekerjasama secara sistematis.

Untuk mengetahui apakah suatu perusahaan dalam menjalankan kegiatan operasionalnya telah sesuai dengan rencana yang ditetapkan, salah satunya adalah dengan mengetahui kinerja perusahaan tersebut. Pengukuran kinerja tersebut dengan menggunakan rasio return on asset (ROA) menunjukkan kemampuan perusahaan dalam memperoleh laba dengan menggunakan harta yang dimiliki oleh perusahaan.

\section{KERANGKA KONSEPTUAL}

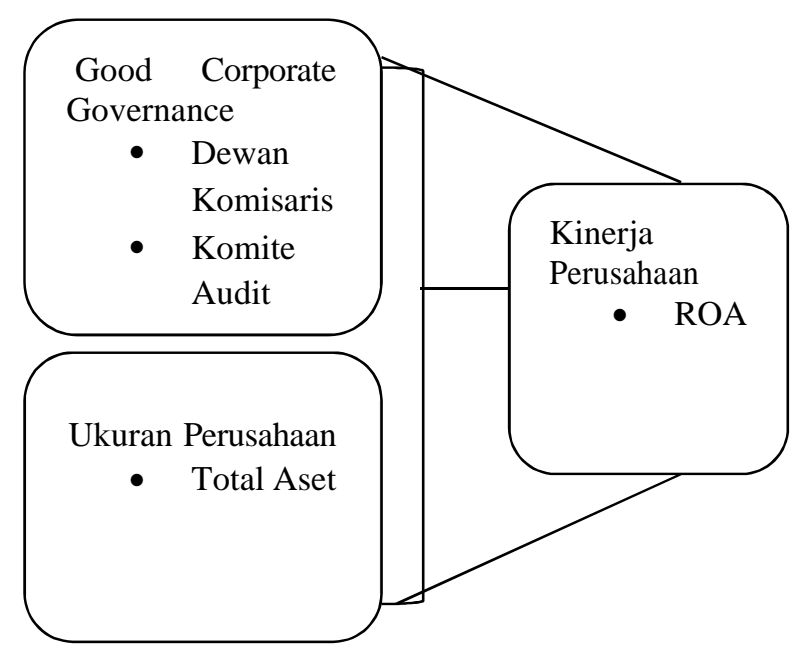

\section{HIPOTESIS}

Berdasarkan uraian tentang teori dan kerangka pemikiran yang melandasi penelitian ini, maka hipotesis penelitian dapat dirumuskan sebagai berikut:

$\mathrm{H}_{1}$ : Good Corporate Governance berpengaruh secara parsial terhadap kinerja keuangan.

$\mathrm{H}_{2}$ : Ukuran Perusahaan berpengaruh secara parsial terhadap kinerja keuangan.

$\mathrm{H}_{3}$ : Good Corporate governance dan Ukuran Perusahaan berpengaruh secara simultan terhadap kinerja keuangan.

\section{III . METODOLOGI PENELITIAN} Jenis Penelitian 
Jenis penelitian ini adalah penelitian kausal, yaitu untuk mengetahui hubungan atau pengaruh dari variabel bebas dan variabel terikat, dengan menggunakan alat analisis yaitu berupa analisis regresi linier berganda, uji $\mathrm{F}$ dan uji t.

\section{Variabel dan Operasional Variabel}

\section{Variabel Independen}

1. Ukuran Dewan Komisaris (Board size)

jumlah Komsaris internal + jumlah komisaris eksternal

2. Komite Audit

Variabel ini menunjukkan jumlah seluruh pihak komite pada tiap bagian komite perusahaan pada periode tahun yang diteliti.

3. Ukuran perusahaan.

Ukuran perusahaan $=\mathrm{Ln}$ total aset

\section{Variabel Dependen}

Kinerja Keuangan perusahaan yang digunakan dalam penelitian ini adalah ROA. Return of Assets (ROA) merupakan rasio yang menunjukkan besarnya laba bersih setelah pajak yang dapat dihasilkan dari rata-rata seluruh kekayaan perusahaan (Wahyudiono, 2013).

\section{ROA = Laba bersih setelah pajak $x 100 \%$ Rata-rata kekayaan}

\section{Populasi dan Sampel Penelitian}

Populasi dalam penelitian adalah perusahaan manufaktur rokok yang tercatat di Bursa Efek Indonesia. Sampel dalam penelitian adalah PT.HM Sampoerna periode 2008-2017.

\section{Jenis dan Sumber Data}

Jenis data yang dibutuhkan untuk mendukung penelitian ini adalah data kuantitatif. Berdasarkan sumbernya, data yang dikumpulkan dalam penelitian ini adalah data sekunder. Data sekunder dalam penelitian ini bersumber dari Bursa Efek Indonesia melalui www.idx.co.id.

\section{Teknik Pengumpulan Data}

Adapun teknik pengumpulan data yang digunakan dalam penelitian ini yaitu melalui studi pustaka.

\section{Metode Analisis}

\section{Statistik deskriptif}

Statistik deskriptif adalah penyajian data secara numerik. Statistik deskriptif menyajikan ukuranukuran numerik yang sangat penting bagi data sampel. Statistik deskriptif digunakan untuk menggambarkan profil data sampel yang meliputi antara lain mean, maksimum, minimum dan standar deviasi.

\section{Uji Asumsi Klasik}

\section{Uji Normalitas}

Uji normalitas adalah pengujian asumsi residual yang berdistribusi normal. Asumsi ini harus terpenuhi untuk model regresi linear yang baik.

\section{Uji Multikolinearitas}

Uji multikolonieritas bertujuan untuk menguji apakah model regresi ditemukan adanya korelasi antarvariabel bebas (independen). Jika hasil penelitian menunjukkan nilai Tolerance $>$ 1,0 dan Variance Inflation Factor (VIF) $\geq 10$ berarti ada multikolinearias, sebaliknya jika nilai Tolerance $<1,0$ dan VIF $<10$ berarti tidak ada multikolonieritas.

\section{Uji Heteroskedastisitas}

Uji Heteroskedastisitas digunakan untuk mengetahui ada atau tidaknya penyimpangan asumsi klasik heteroskedastisitas yaitu adanya ketidaksamaan varian dari residual untuk semua pengamatan pada model regresi.

\section{Uji Autokorelasi}

Autokorelasi digunakan untuk mengetahui ada atau tidaknya penyimpangan asumsi klasik autokorelasi yaitu korelasi yang terjadi antara residual pada satu pengamatan dengan pengamatan lain pada model regresi.

\section{Uji Regresi Linear Berganda}

Analisis data dalam penelitian ini dilakukan dengan metode deskriptif dengan alat analisis regresi berganda. Perhitungan dilakukan dengan menggunakan bantuan program SPSS .

$$
\mathrm{Y}=\mathrm{a}+\mathrm{b} 1 \mathrm{X} 1+\mathrm{b} 2 \mathrm{X} 2+\mathrm{e}
$$


keterangan :

$$
\begin{aligned}
\mathrm{Y} & =\text { ROA }(\text { return on assets }) \\
\alpha & =\text { konstanta } \\
\mathrm{B} 1 \ldots \mathrm{b} 2 & =\text { koofisien } \\
\mathrm{X} 1 & =\text { Good Corporate Governance } \\
\mathrm{X} 2 & =\text { Ukuran Perusahaan } \\
\mathrm{e} & =\text { error term }
\end{aligned}
$$

\section{Pengujian Hipotesis}

\section{Uji F ( pengujian secara simultan )}

Uji $F$ digunakan untuk menguji pengaruh variabel independen terhadap variabel dependen secara bersama-sama.

$$
F=\frac{R^{2} /(k-1)}{\left(1-R^{2}\right) /(n-k)}
$$

Keterangan :

$\mathrm{R}^{2}=$ Koefisien determinasi

$\mathrm{N}=$ Jumlah sampel penelitian (jumlah observasi)

$\mathrm{k}=$ Jumlah variabel independen (prediktor) termasuk konstanta (intersep)

\section{Uji T ( pengujian secara parsial )}

Bertujuan untuk mengetahui pengaruh variabel independen terhadap variabel dependen secara parsial. Diatas adalah rumus penentuan nilai t-

hitung ( uji T ). $\quad t=\frac{\bar{x}-\mu_{0}}{\frac{s}{\sqrt{n}}}$

\section{Koofisien Determinasi $\left(\mathbf{r}^{2}\right)$}

$\mathrm{R} 2$ adalah perbandingan antara variasi $\mathrm{Y}$ yang dijelaskan oleh $\mathrm{x} 1$ dan $\mathrm{x} 2$ secara bersama-sama dibanding dengan variasi total $\mathrm{Y}$.

\section{HASIL PENELITIAN DAN PEMBAHSAN}

\section{Analisis Deskriptif}

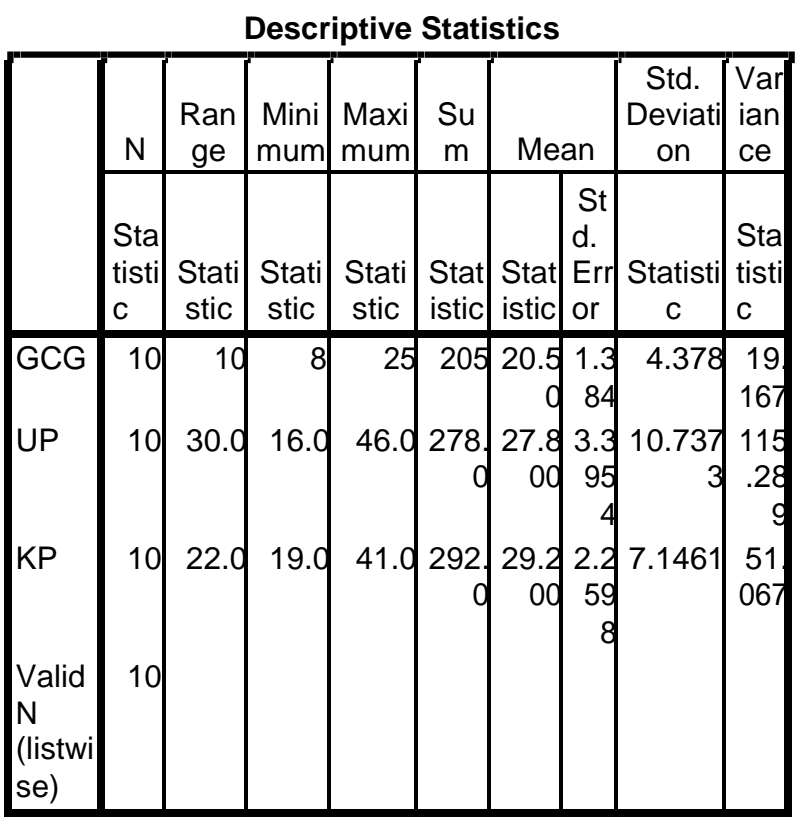

(Sumber: output pengolahan data dengan SPSS

17)

Berdasarkan tabel diatas hasil analisis statistik deskriptif menunjukkan observasi penelitian pada perusahaan PT.HM Mandala Sampoerna Tbk Periode 2008-2017 berjumlah 10 tahun. Variabel dependen yaitu Kinerja Perusahaan menunjukkan nilai terendah sebesar 19,0 yang terjadi pada tahun 2013. Hal ini menunjukkan bahwa pada tahun 2013 PT.HM Mandala Sampoerna Tbk memiliki tingkat

kinerja perusahaan yang rendah dibandingkan tahun lainnya. Variabel independen good corporate governance menunjukkan nilai terendah sebesar 8 ini menunjukan Corporate governance yang lemah dan menjadi salah satu penyebab terjadinya kinerja perusahaan yang lemah pada tahun 2008. Ciri utama dari lemahnya corporate governance adalah adanya tindakan mementingkan diri sendiri di pihak manajer perusahaan.

Variabel independen Ukuran Perusahaan menunjukkan nilai terendah sebesar 16 , dengan demikian nilai terendah ukuran perusahaan terjadi pada tahun 2008.

\section{Uji Asumsi Klasik}

\section{Uji Normalitas Histogram}

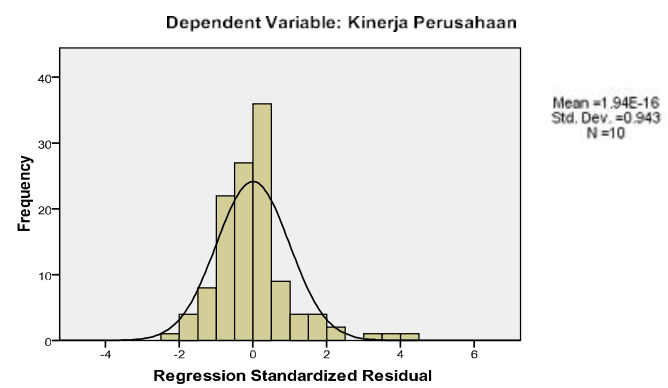


Dari gambar histrogram diatas dapat disimpulkan bahwa grafik histogram memberikan pola distribusi yang normal, dikatakan normal dikarenakan berbentuk simetris atau tidak menceng. Hal ini menunjukan bahwa model regresi memenuhi asumsi normalitas.

\section{Grafik Uji Normalita Probability Plot}

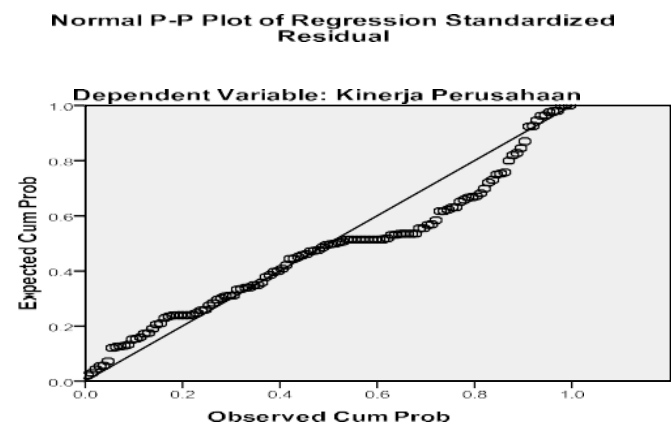

Sumber : Data olah statistik (SPSS 17, 2018) Data dikatakan normal apabila pada gambar grafik titik-titik terlihat menyebar disekitar garis diagonal dan mengikuti arah garis diagonal, dan pada gambar grafik Normal Probability plot diatas menunjukan bahwa titik-titik terlihat menyebar disekitar garis diagonal dan mengikuti arah garis diagonalnya

\section{Hasil Uji Normalitas Kolmogorov-smirnov}

One-Sample Kolmogorov-Smirnov Test

\begin{tabular}{|c|c|c|c|c|}
\hline & & $\begin{array}{c}\text { Good } \\
\text { Corporate } \\
\text { Governan } \\
\text { ce } \\
\end{array}$ & $\begin{array}{c}\text { Ukuran } \\
\text { Perusah } \\
\text { aan }\end{array}$ & $\begin{array}{c}\text { Kiner } \\
\text { ja } \\
\text { Perus } \\
\text { ahaan }\end{array}$ \\
\hline \multicolumn{2}{|l|}{$\mathrm{N}$} & 10 & 10 & 10 \\
\hline \multirow{2}{*}{$\begin{array}{l}\text { Normal } \\
\text { Parameters }{ }^{\mathrm{a}, \mathrm{b}}\end{array}$} & Mean & 51.46 & 50.18 & 50.24 \\
\hline & $\begin{array}{l}\text { Std. } \\
\text { Deviation }\end{array}$ & 8.911 & 9.322 & 9.522 \\
\hline \multirow{3}{*}{$\begin{array}{l}\text { Most Extreme } \\
\text { Differences }\end{array}$} & Absolute & .160 & .143 & .148 \\
\hline & Positive & .126 & .096 & .092 \\
\hline & Negative & -.160 & -.143 & -.148 \\
\hline \multicolumn{2}{|c|}{ Kolmogorov-Smirnov Z } & 1.753 & 1.561 & 1.624 \\
\hline \multicolumn{2}{|c|}{ Asymp. Sig. (2-tailed) } & .304 & .215 & .110 \\
\hline
\end{tabular}

a. Test distribution is Normal.

b. Calculated from data.

Sumber : Data olah statistik (SPSS 17, 2018)

Berdasarkan tabel 4.2 hasil uji normalitas menunjukkan bahwa nilai Kolmogorov-Smirnov Z Good Corporate Governance adalah sebesar 1,753, Ukuran perusahan sebesar 1.561, dan kinerja perusahaan sebesar 1.624 sedangkan nilai Asymp.Sig. (2-tailed) > 0,05 yang berarti residual model regresi berdistribusi normal.

\section{Uji Multikolinearitas}

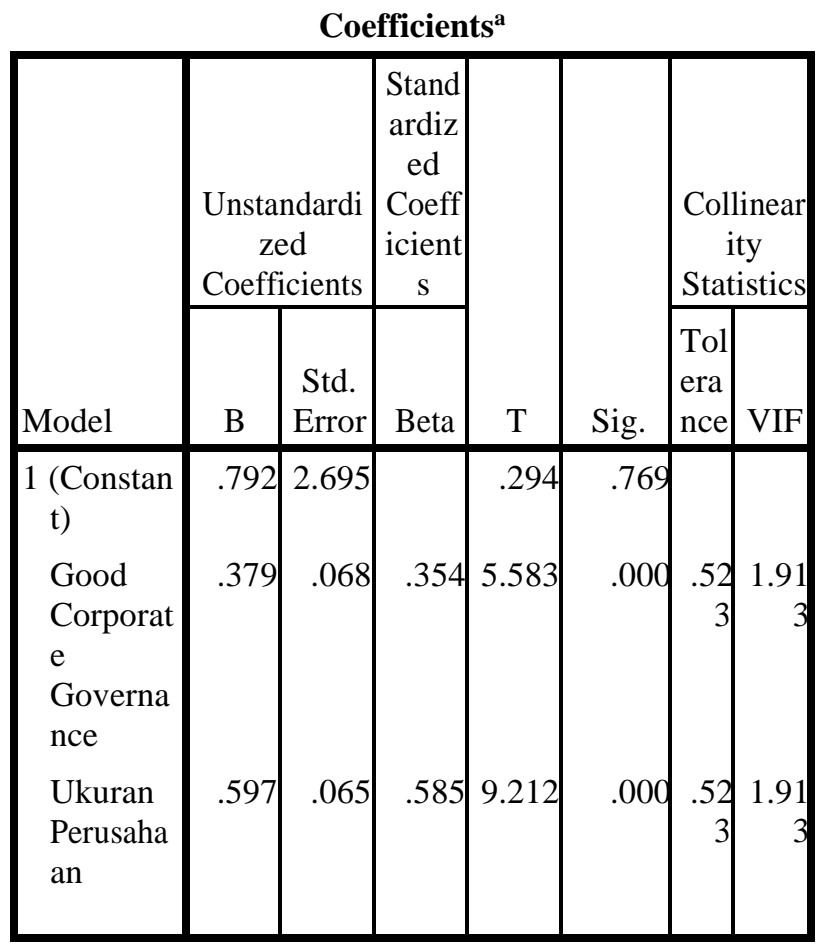

a. Dependent Variable: Kinerja Perusahaan

Sumber : Data olah statistik (SPSS 17, 2018)

Dari tabel diatas menunjukan bahwa nilai VIF variabel good corporate governance dan ukuran perusahaan sebesar 1,913. Semua nilai VIF di atas lebih kecil dari 10 atau VIF < 10 maka tidak terjadi gejala multikolinearitas. Sedangkan nilai Tolerance untuk variabel good corporate governance dan ukuran perusahaan sebesar 0,523 . Nilai tolerance masing-masing variabel di atas 0,10 dapat dikatakan bahwa tidak terjadi gejala multikolinearitas diantara variabel bebas.

\section{Uji Autokorelasi}




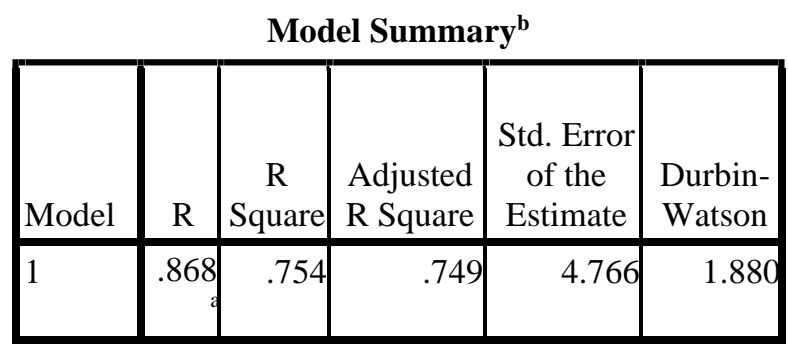

a. Predictors: (Constant), Ukuran Perusahaan, Good Corporate Governance

b. Dependent Variable: Kinerja Perusahaan

Sumber : Data olah statistik (SPSS 17, 2018) Berdasarkan uji durbin watson dengan program spss diperoleh nilai durbin watson sebesar 1.880 akan dibandingkan dengan nilai tabel dengan menggunakan derajat kepercayaan $5 \%$ atau $(0,05)$ dengan jumlah sample 10 dan jumlah variabel bebas 2 , maka di tabel durbin watson akan diperoleh nilai dl 0,6972 dan du 1,6413 karena nilai $\mathrm{dw}$ berada pada $\mathrm{du}<\mathrm{dw}<4$ du, maka dapat disimpulkan bahwa tidak terjadi autokorelasi.

\section{Uji Heteroskedastisitas}

Uji ini bertujuan untuk mengetahui apakah ada ketidak samaan varian dari residual untuk semua pengamatan pada model regresi linier. Dalam penelitin ini, peneliti menggunakan Scatterplot untuk menguji ada tidaknya Heterokedasitas.

\section{Grafik Scatterplot}

Sumber : Data olah statistik (SPSS 17, 2018)

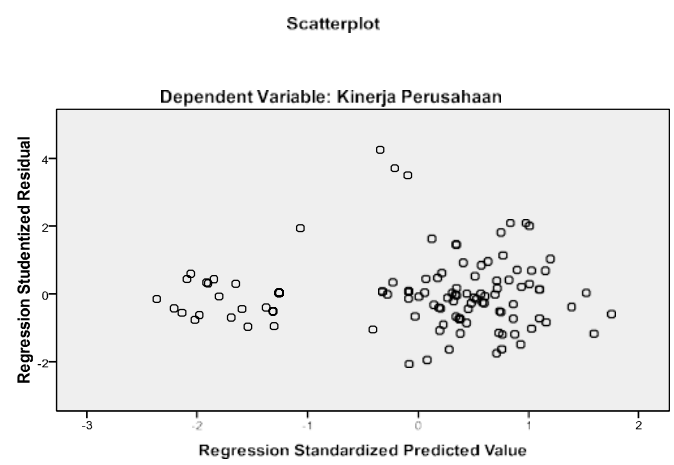

Data dikatakan tidak terjadi heterokedasitas apabila tidak ada pola yang jelas serta titik-titik menyebar secara acak dan dibawah angka 0 pada sumbu Y dan pada gambar diatas terlihat bahwa tidak ada pola yang jelas serta titik-titik menyebar secara acak dan dibawah angka 0 pada sumbu Y, sehinga dapat disimpulkan bahwa tidak terjadi heterokedasitas pada penelitian ini.

\section{Analisis Regresi Linier Berganda}

Dalam penelitian ini diperoleh hasil koefisien regresi linier berganda sebagai berikut.

\section{Hasil Uji Regresi Linier Berganda}

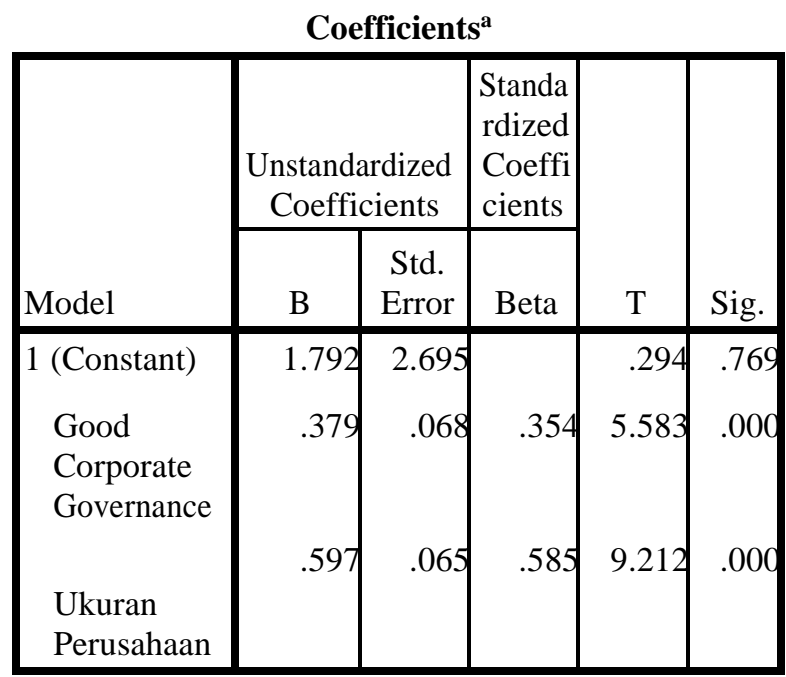

a. Dependent Variable: Kinerja Perusahaan

Sumber : Data olah statistik (SPSS 17, 2018)

Berdasarkan tabel diatas diperoleh persamaan regresi yaitu sebagai berikut :

$$
\begin{gathered}
Y=a+b 1 \times 1+b 2 \times 2+e \\
Y=1,792+0,379 \times 1+0,597 \times 2+0,05
\end{gathered}
$$

Keterangan:

1. Nilai konstanta sebesar 1,792 , artinya jika good corporate governance (X1) dan ukuran perusahaan (X2) dianggap konstan maka nilai dari kinerja perusahaan (Y) adalah sebesar 1,792.

2. Koefisien regresi good corporate governance (X1) nilainya 0,379 artinya jika good corporate governance (X1) mengalami kenaikan, maka kinerja perusahaan (Y) mengalami peningkatan sebesar 0,379 atau $37,9 \%$.

3. Koefisien regresi ukuran perusahaan (X2) 0,597 artinya jika ukuran perusahaan (X2) mengalami kenaikan, maka tingkat kinerja perusahaan (Y) mengalami peningkatan sebesar 0,597 atau $59,7 \%$.

\section{Uji Hipotesis Secara Parsial atau Uji t}

Uji t dilakukan dengan melihat nilai signifikansi $t$ pada variabel good coporate governance dan ukuran perusahaan dengan nilai signifikansi $0,050(\alpha=5 \%)$. 
Hasil uji t dapat dilihat pada Tabel 4.5 dengan nilai t hitung good corporate governance sebesar 5,583 dan $\mathrm{t}$ hitung ukuran perusahaan sebesar 9,212 . Sedangkan nilai $t$ tabel pada nilai signifikansi 0,050 adalah 1,860. Dengan demikian $\mathrm{t}$ hitung $>\mathrm{t}$ table maka :

1. "Good corporate governance berpengaruh positif dan signifikan terhadap kinerja perusahaan PT.HM Mandala Sampoerna Tbk Periode 20082017" diterima.

2. "Ukuran perusahaan berpengaruh positif dan signifikan terhadap kinerja perusahaan PT.HM Mandala Sampoerna Tbk Periode 2008-2017" diterima.

\section{Uji Hipotesis Secara Anova atau Uji F}

\begin{tabular}{|l|c|r|r|r|r|r|}
\hline \multicolumn{7}{|c|}{ ANOVA $^{\mathbf{b}}$} \\
\hline Model & $\begin{array}{l}\text { Sum of } \\
\text { Squares }\end{array}$ & Df & $\begin{array}{c}\text { Mean } \\
\text { Square }\end{array}$ & F & Sig. \\
\hline $1 \begin{array}{l}\text { Regres } \\
\text { sion }\end{array}$ & 8131.935 & 2 & 4065.96 & 178.972 & .000 \\
& $\begin{array}{l}\text { Residu } \\
\text { al }\end{array}$ & 2658.056 & 7 & 22.718 & & \\
& Total & 10789.992 & 9 & & & \\
\hline
\end{tabular}

a. Predictors: (Constant), Ukuran Perusahaan, Good Corporate Governance

b. Dependent Variable: Kinerja Perusahaan

Dari uji anova atau $\mathrm{F}$ test didapat $\mathrm{F}$ hitung sebesar 178,972 dengan $F$ tabel sebesar 4,46 dengan tingkat signifikan 0,000 karena probability jauh lebih kecil dari 0,050 maka good corporate governance dan ukuran perusahaan secara bersama-sama berpengaruh signifikan terhadap kinerja perusahaan, berarti Ho ditolak Ha diterima. Dengan demikian hipotesis ketiga : "good corporate governance dan ukuran perusahaan secara bersama-sama berpengaruh signifikan terhadap kinerja perusahaan PT.HM Mandala Sampoerna Tbk Periode 2008-2017" dapat diterima.

\section{Koefisien Determinasi}

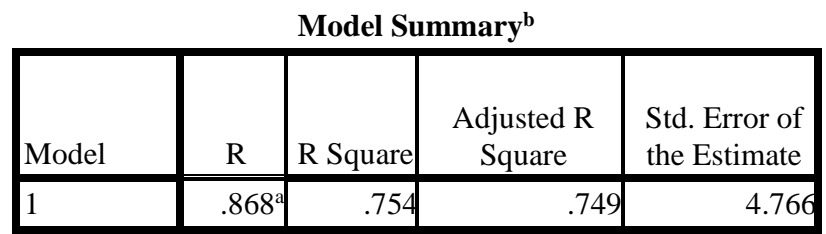

a. Predictors: (Constant), Ukuran Perusahaan, Good Corporate Governance

b. Dependent Variable: Kinerja Perusahaan
Dari tabel di atas memperlihatkan keeratan pengaruh variabel Good Corporate Governance dan Ukuran Perusahaan terhadap Kinerja Perusahaan. Hasil perhitungan diperoleh $R_{X_{1} X Y}=$ 0,868 dan koefisien determinasi sebesar $R_{X X_{1} Y}^{2}=$ 0,754 atau $75,4 \%$. Besarnya koefisien determinasi, memberikan arti bahwa besarnya perubahan pada variabel Kinerja Perusahaan $75,4 \%$ dipengaruhi oleh Good Corporate Governance dan Ukuran Perusahaan, sedangkan sisanya $24,6 \%$ dipengaruhi oleh faktor lain.

\section{KESIMPULAN DAN SARAN}

\section{Kesimpulan}

Berdasarkan hasil analisis dan pembahasan, maka diperoleh kesimpulan sebagai berikut :

1. Secara parsial good corporate governance berpengaruh positif dan signifikan terhadap kinerja perusahaan PT.HM Sampoerna Tbk Periode 20082017.

2. Secara parsial ukuran perusahaan berpengaruh positif dan signifikan terhadap kinerja perusahaan PT.HM Sampoerna Tbk Periode 2008-2017.

3. Secara anova atau simultan good corporate governance dan ukuran

4. perusahaan secara bersama-sama berpengaruh signifikan terhadap kinerja perusahaan PT.HM Sampoerna Tbk Periode 2008-2017.

\section{Saran}

Saran-saran yang dapat diberikan sebagai tindak lanjut dari hasil penelitian adalah sebagai berikut:

1. Bagi Pihak PT.HM Mandala Sampoerna Tbk.

a. Rendahnya Corporate governance yang lemah dapat menjadi salah satu penyebab terjadinya kinerja perusahaan yang ikut lemah. Ciri utama dari lemahnya corporate governance adalah adanya tindakan mementingkan diri sendiri di pihakpihak yang penting dalam perusahaan seperti manager perusahaan. Maka dari itu diharapkan pihak perusahaan meningkatkan sistem corporate governance agar kinerja perusahaan meningkat

b. Rendahnya ukuran perusahaan seperti yang terjadi pada tahun 2011, menjadi tolak ukur dalam kinerja 
perusahaan, maka dari itu di harapkan pihak

c. perusahaan dapat meningkatkan ukuran perusahaan agar kinerja perusahaan meningkat.

2. Bagi Peneliti

Hasil peneiltian diharapkan dapat memberikan konstribusi dalam bidang ilmu manajemen, khususnya dibidang keuangan dan memberikan tambahan informasi kepada peneliti dibidang manajemen keuangan lainnya sebagai pijakan untuk penelitian selanjutnya terutama penelitian tentang kinerja perusahaan.

\section{DAFTAR PUSTAKA}

Achmad, Fauzi. (2009). Analisis Pengaruh Penerapan Good Corporate Governance terhadap Kualitas Laba. Akuntansi, Fakultas Ekonomi,Universitas Lampung.

Agus, Sartono. (2010) . Manajemen Keuangan Teori dan Aplikasi. Edisi 4. Yogyakarta: BPFE, 249.

Agustami, Silviana. (2016). Pengaruh Good Corporate Governance dan Ukuran Perusahaan terhadap Kinerja Keuangan Perusahaan. Jurnal Riset Akuntansi dan Keuangan, Vol 4(2), 1035-1046.

Badan Pengawas Pasar Modal (BAPEPAM) No.SE-03/PM/2000. Tentang Komite Audit

Bambang, Riyanto. (2008). Dasar-Dasar Pembelanjaan Perusahaan. Yogyakarta: GPFE, 313.

Darmawati,Deni, Khomsiyah, dan Rika Gelar Rahayu. (2004). Hubungan Corporate governance dan Kinerja Perusahaan. Simposium Nasional Akuntansi, VII, IAI, 2004.

Diandono, Hudan. (2012). Pengaruh Mekanisme Good Corporate Governance (GCG) Terhadap Kinerja Perusahaan Yang Masuk Kelompok Jakarta Islamik Indeks (JII) Periode 2006-2011. Fakultas Syari'ah dan Hukum,Universitas Islam Negeri Sunan Kalijaga. Yogyakarta. (dipublish)

Forum For Corporate Governance in Indonesia (FCGI). (2002). Seri Tata Kelola Perusahaan-Corporate Governance, Jilid I, II, III. Edisi ke-2. Jakarta . (FCGI). (2009). Peranan Dewan Komisaris dan Komite Audit dalam Pelaksanaan Tata Kelola
Perusahaan. Seri Tata Kelola Jilid II. Jakarta

Gumilang, Bayu Sri. (2018). Pengaruh Good Corporate Governance terhadap Kinerja Keuangan. Universitas Muhammadiyah Surakarta.

Husnan, Suad. (2011). Corporate Governance dan Keputusan Pendanaan:

Perbandingan Kinerja Perusahaan dengan Pemegang Saham Pengendali Perusahaan Multinasional dan Bukan Multinasional. Jurnal Riset Manajemen Vol 1. No 1.

Izzati, Laili. (2011) . Analisis Hubungan Penerapan Good Corporate Governance Dengan Kinerja Keuangan Perusahaan (Studi Kasus Pada Beberapa Perusahaan Non Keuangan yang Listing di Bursa Efek Indonesia).Universitas Gunadarma. Fakultas ekonomi. (dipublish)

Kasih, Ayu Permata. (2014). Pengaruh Good Corporate Governance dan Ukuran Perusahaan terhadap Kinerja Perusahaan. Universitas Muhammadiyah Surakarta.

Keputusan Menko Ekuin No: KEP/31/M.EKUIN/08/1999.Tentang

Pembentukkan Komite Nasional Kebijakkan Corporate Governance (KNKCG)

Keputusan Menteri BUMN, KEP-117/MMBU/2002. Tentang Penerapan Praktek Good Corporate Governance dan BUMN

Komite Nasional Kebijakkan Governance (KNKG). (2006). Pedoman Umum Good Corporate Governance di Indonesia. (KNKG). (2013). Pedoman Umum Good Corporate Governance di Indonesia.

Malerret, Clery Sean and Thierry. (2008). Berbisnis dengan Osama Mengubah Resiko Global Menjadi Peluang Sukses. Jakarta: Serambi Ilmu Semesta, 233.

Moeljono, Djokosantoso. (2005). Budaya Organisasi Dalam Tantangan. Jakarta: Elex Media Komputindo.

Peraturan BI No.8/4/PBI/2006. Tentang Pelaksanaan Good Corporate Governance

Pratiwi, Ryan Anugrah. (2017). Pengaruh Good Corporate Governance dan ukuran Perusahaan terhadap Nilai Perusahaan pada Perusahaan Food and Beverage yang Listing di Bursa Efek Indonesia. Universitas Riau. 
Riyanto,Ardian. (2011) “Analisis Pengaruh Mekanisme Good Corporate Governance Dan Privatisasi Terhadap Kinerja Keuangan (Studi Pada Bumn Yang Tercatat Di Bursa Efek Indonesia Periode Privatisasi 2002-2006)".

Fakultas Ekonomi, Universitas Diponegoro. Semarang.

Robbins, S.P. (2006). Organizational Behavior. 9th edition. New Jersey: Prentice Hall, Inc.

Scott, W.R. (2012). Financial Accounting Theory $6^{\text {th }}$ Edition. Toronto: Peason Education Canada, 93.

Sembiring, Seniwati. (2008). Pengaruh Ukuran Perusahaan dan Kebijakan Pendanaan terhadap Kinerja Keuangan pada

$B U M N$. Jurnal manajemen, Vol. 2 (4).

Sukamulya, Sukmawati. (2004). Good Corporate Governance di Sektor Keuangan: Dampak Good Corporate Governance terhadap Kinerja Keuangan, Vol 8. No 1.

Suranta, E. dan P. P. Midiastuty, (2003), "Analisis Hubungan Struktur Kepemilikan Manajerial, Nilai Perusahaan dan Investasi dengan Model Persamaan Linear Simultan", Jurnal Riset Akuntansi Indonesia, Vol. 6, No. 1.

Surya, I., \& Yustiavandana, I. (2006). Penerapan

Good Corporate Governance:

Mengesampingkan Hak-hak Istimewa

Demi Kelangsungan Usaha. Kencana, diterbitkan atas kerja sama dengan Lembaga Kajian Pasar Modal dan Keuangan, Fakultas Hukum, Universitas Indonesia. (2006). Penerapan Good

Corporate Governance:

Mengesampingkan Hak-hak Istimewa Demi Kelangsungan Usaha. Kencana, diterbitkan atas kerja sama dengan Lembaga Kajian Pasar Modal dan Keuangan, Fakultas Hukum, Universitas Indonesia, 135-149 .

Undang-Undang No.1 Tahun 1995 Tentang Perseroan Terbatas

Undang-Undang No.40 Tahun 2007 Tentang Perseroan Terbatas

Veno, Andri. (2015). Pengaruh Good Corporate Governance terhadap Kinerja Perusahaan pada Perusahaan Manufaktur Go Public. Jurnal Manajemen dan Bisnis Vol 19, No 1, Universitas Muhammadiyah Surakarta, 95-112.

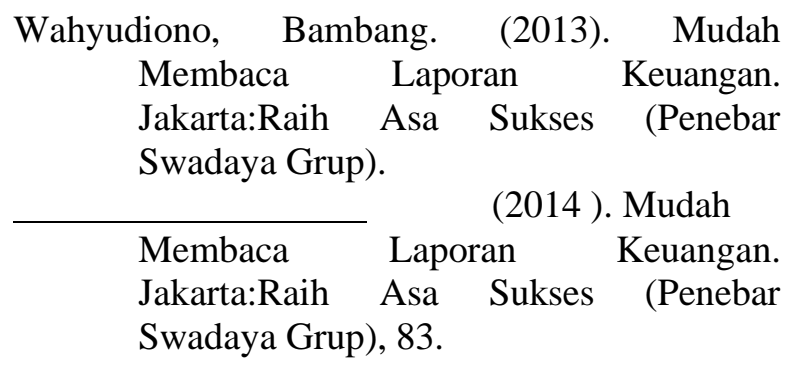

\section{WWW.IDX.CO.ID}


